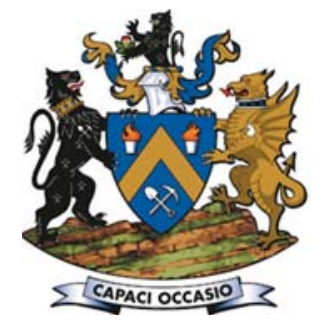

\title{
Influences of alkali fluxes on direct reduction of chromite for ferrochrome production
}

\author{
by D. Paktunc*, Y. Thibault*, S. Sokhanvaran*, and D. Yu*
}

\section{Synopsis}

Prereduction and flux-aided direct reduction of chromite provide significant advantages in reducing energy consumption and greenhouse gas emissions during ferrochrome production. In this investigation, a comparative evaluation of the influences of several alkali fluxes was carried out based on experimental observations supplemented by advanced material characterization and thermodynamic predictions. Direct reduction of a chromite ore with alkali fluxes at $1300^{\circ} \mathrm{C}$ for 1 hour produced $(\mathrm{Cr}, \mathrm{Fe})_{7} \mathrm{C}_{3}$ type alloys with $\mathrm{Cr} / \mathrm{Fe}$ mass ratios from 0.7 to 2.3. Among the alkali fluxes, reduction aided by $\mathrm{NaOH}$ resulted in a high degree (85\%) of $\mathrm{Cr}$ metallization with the ferrochrome alloy being $\mathrm{Cr}_{4.2-4.6} \mathrm{Fe}_{2.4-2.8} \mathrm{C}_{3}$. The formation of liquid slag, which facilitated $\mathrm{Cr}$ metallization, was limited by the formation of $\mathrm{NaAlO}_{2}$ between 800 and $1300^{\circ} \mathrm{C}$. This, in turn, restricted the collection and transport of the charged ionic $\mathrm{Cr}$ species (i.e. $\mathrm{O}^{2-}$ ) to graphite particles. Under the conditions studied, ferrochrome particles were often small and largely unliberated, which would make the physical recovery of ferrochrome challenging. At $1400^{\circ} \mathrm{C}$, the amount of liquid slag increased, enabling the growth of alloy particles. Direct reduction of chromite aided by $\mathrm{NaOH}$ is promising as an alternative technology to conventional flux-based smelting in electric arc furnaces.

\section{Keywords}

chromite, ferrochrome, direct reduction, prereduction, smelting, carbothermic reaction, alkali flux.

\author{
Introduction \\ Conventional smelting processes are energy- \\ intensive (Riekkola-Vanhanen, 1999) with the \\ energy requirements greater than $4 \mathrm{MWh} / \mathrm{t}$ \\ (Naiker and Riley, 2006; Beukes, van Zyl, and \\ Neizel, 2015), and the greenhouse gas \\ emissions can be significant, exceeding $10.5 \mathrm{t}$ \\ $\mathrm{CO}_{2}$ per ton $\mathrm{Cr}$ in ferrochrome produced \\ (International Chromium Development \\ Association, 2016). These include emissions \\ occurring on-site (smelter), emissions due to \\ electricity production, and emissions due to \\ upstream processes. Overall energy \\ requirements are influenced by the degree of \\ prereduction and smelter charge temperature. \\ Significant reduction in electricity consumption \\ can be realized if the charge is prereduced \\ before feeding to the submerged arc furnace \\ (Niayesh and Fletcher, 1986). This \\ consideration has led to the development of \\ several prereduction technologies, with the \\ most important example being the Premus
}

process. In comparison to the conventional smelting processes, this prereduction process lowers the overall energy consumption and greenhouse gas emissions by about one-third (Naiker, 2007).

Prereduction of chromite with the use of various fluxes or additives has been the topic of many studies over at least three decades. The additives tested since 1986 include borates, $\mathrm{NaCl}, \mathrm{NaF}$, and $\mathrm{CaF}_{2}$ (Katayama, Tokuda, and Ohtani, 1986), $\mathrm{CaF}_{2}$ and $\mathrm{NaF}$ (Dawson and Edwards, 1986), $\mathrm{K}_{2} \mathrm{CO}_{3}, \mathrm{CaO}$, $\mathrm{SiO}_{2}, \mathrm{Al}_{2} \mathrm{O}_{3}$, and $\mathrm{MgO}$ (van Deventer, 1988), granite and $\mathrm{CaF}_{2}$ (Nunnington and Barcza, 1989), $\mathrm{SiO}_{2}$ (Weber and Eric, 1992; Lekatou and Walker, 1997), Portland cement, lime, and $\mathrm{SiO}_{2}$ (Takano et al., 2007), $\mathrm{CaO}$ and $\mathrm{SiO}_{2}$ (McCullough et al., 2010), $\mathrm{CaCO}_{3}$ (Neizel et al., 2013), and $\mathrm{MgO}, \mathrm{CaO}, \mathrm{SiO}_{2}$ and $\mathrm{Al}_{2} \mathrm{O}_{3}$ (Wang, Wang, and Chou, 2015). Since the filing of the patent application on the use of several alkalis as the accelerants (Winter, 2015; Barnes, Muinonen, and Lavigne, 2015), we have been performing systematic studies to improve our understanding of the roles of various fluxes. Our studies involved using $\mathrm{NaCl}, \mathrm{NaOH}$, $\mathrm{Na}_{2} \mathrm{CO}_{3}, \mathrm{CaCl}_{2}, \mathrm{Ni}$, and a metallurgical waste product as the fluxes in accelerating the reduction of chromite and developing a fundamental understanding of the kinetics and mechanisms of reduction and metallization (Sokhanvaran and Paktunc, 2017, 2018; Sokhanvaran, Paktunc, and Barnes, 2018; Yu and Paktunc, 2017; Yu and Paktunc, 2018a, $2018 b, 2018 c)$. These studies formed parts of the broader research into improving and optimizing the conventional smelting processes as well as developing new reduction technologies to reduce energy demands and greenhouse gas emissions, and evaluating the

* CanmetMINING, Natural Resources Canada, Canada.

(C) The Southern African Institute of Mining and Metallurgy, 2018. ISSN 2225-6253. Paper received May 2018; revised paper received Jul. 2018. 


\section{Influences of alkali fluxes on direct reduction of chromite for ferrochrome production}

development of direct reduction of chromite as an alternative ferrochrome production technology. Direct reduction of chromite can be defined as the production of ferrochrome from chromite ore using a carbon reductant but without melting/reduction in electric arc furnaces. Although direct reduction of iron is well known and widely practiced as an industrial process for producing pig iron, direct reduction of chromite has not been tested until recently. The SRC process developed in Japan in the 1970s can be considered direct reduction if it is used as a stand-alone process. Previous studies considered the use of various fluxes in a prereduction process prior to smelting in electric arc furnaces and as such, they differ in philosophy from the direct reduction process. In this paper, we present our study results in a comparative manner to illustrate the influence of the three alkali compounds in the direct reduction of chromite.

\section{Materials and methods}

An ore sample from the Black Thor deposit from the Ring of Fire area in northern Ontario was ground and sieved to $-106+75 \mu \mathrm{m}$ size range. The ore, with a grade of $43.12 \mathrm{wt} \%$ $\mathrm{Cr}_{2} \mathrm{O}_{3}$ and $\mathrm{Cr} / \mathrm{Fe}$ ratio of $1.97\left(21.4 \mathrm{wt} \% \mathrm{Fe}_{2} \mathrm{O}_{3}\right)$, was blended with graphite as the reductant and an alkali flux $(\mathrm{NaCl}$, $\mathrm{NaOH}$, or $\mathrm{Na}_{2} \mathrm{CO}_{3}$ ) in the proportions of 100:22:12 (by weight) unless otherwise indicated in the text. The ore contained $84 \mathrm{wt} \%$ chromite, with an average composition of $\left(\mathrm{Mg}_{0.4} \mathrm{Fe}_{0.6}\right)\left(\mathrm{Cr}_{1.3} \mathrm{Al}_{0.5} \mathrm{Fe}_{0.1}\right) \mathrm{O}_{4}$, and $16 \mathrm{wt} \%$ clinochlore with the average formula of $\mathrm{Si}_{6.0} \mathrm{Al}_{3.3} \mathrm{Cr}_{0.5} \mathrm{Mg}_{9.9} \mathrm{Fe}_{0.2} \mathrm{O}_{20}(\mathrm{OH})_{16}$ based on ModAn estimates (Paktunc, 2001). The mixture was homogenized prior to the experimental studies.

The experiments were performed in a sealed vertical tube furnace with $\mathrm{MoSi}_{2}$ heating elements. The sample, weighing $60 \mathrm{~g}$, was placed in an alumina crucible suspended in the furnace by a tungsten wire and the tests were conducted at 1100 and $1300^{\circ} \mathrm{C}$ for periods of 45 and 60 minutes under $\mathrm{Ar}$ atmosphere at a flow of $900 \mathrm{~mL} / \mathrm{min}$. Following reduction, the crucible was raised to the upper zone of the furnace and cooled in Ar. Off-gases were continuously analysed by an infrared gas analyser.

The samples were also subjected to thermogravimetry and differential scanning calorimetry (TG-DSC) analyses under Ar atmosphere with continuous gas analysis. TG-DSC analysis was performed using a NETZSCH STA 449C simultaneous thermal analyser coupled to a NETZSCH QMS 403C Aeolos mass spectrometer. For each test, a sample of 42 mg was placed inside an alumina crucible before loading it into the TG-DSC. After closing the top of the instrument, the atmosphere surrounding the crucibles inside the TG-DSC was purged with a vacuum to remove air. A controlled flow of ultra-high purity argon was introduced and maintained as an inert carrier gas for the duration of each test. The sample was quickly heated from room temperature to $700^{\circ} \mathrm{C}$, followed by heating at $10^{\circ} \mathrm{C} / \mathrm{min}$ to the target temperature and held for a specified time before being rapidly cooled to room temperature under argon atmosphere.

The products formed during carbothermic reduction in the sealed tube furnaces were characterized by X-ray diffraction, optical microscopy, scanning electron microscopy, and electron microprobe analysis and, at the molecular-scale, by synchrotron-based X-ray techniques. Electron microprobe analysis (JEOL JXA-8900) involved wavelength-dispersive X- ray microanalysis on polished sections at an accelerating voltage of $20 \mathrm{kV}$. Individual quantitative analyses were done using a probe current of 10 to $35 \mathrm{nA}$ and counting times ranging from 10 up to 60 seconds on peak and background. $\mathrm{Na} \mathrm{K} \alpha \mathrm{X}$-ray intensity was monitored as a function of time to ensure that there was no Na mobility under the analytical conditions used. Estimation of the distribution of $\mathrm{Fe}^{3}+$ and $\mathrm{Fe}^{2+}$ in the chromite analyses was based on stoichiometry to balance the charge from the ideal spinel formula $\left(\mathrm{Mg}, \mathrm{Fe}^{2+}\right)\left(\mathrm{Cr}, \mathrm{Al}, \mathrm{Fe}^{3}+\right)_{2} \mathrm{O}_{4}$. Carbon concentration in the metallic phase was determined by difference from a total of $100 \%$, an approach consistent for crystalline $\mathrm{M}_{7} \mathrm{C}_{3}$ type carbides. Matrix corrections were made using the $\Phi(\rho z)$ program provided by JEOL to take into considerations matrix effects introduced by compositional differences between the unknowns and standards.

Mineral quantities and liberation were determined using a TESCAN Integrated Mineral Analyzer (TIMA) equipped with four silicon-drifted energy-dispersive X-ray detectors. The analyses were done at an accelerating voltage of $25 \mathrm{kV}$ and a beam current of $5.5 \mathrm{nA}$ using the high-resolution mapping mode with a step size of $0.5 \mu \mathrm{m}$.

Synchrotron-based X-ray absorption near-edge spectroscopy (XANES) spectra were collected at bending magnet and insertion device beamlines. Bulk XANES spectra were collected in transmission mode on finely ground samples spread onto tape as monolayers. Micro-XANES spectra were collected using a $2 \mu \mathrm{m}$ beam and confocal microchannel array optics. The confocal method provides 2-5 $\mu \mathrm{m}$ depth resolution and limits detection of emissions to small volumes of materials at specified depths along the path of the focused beam through the sample. Data reduction and analysis were done by ATHENA (Ravel and Newville, 2005) and the least-squares fitting analyses of the XANES spectra were performed with LSFitXAFS (Paktunc, 2004).

In support of the experimental and characterization studies, thermodynamic simulations were performed using FactSage with the input parameters being identical to those of the experimental studies (i.e. mass proportions of ore:graphite:flux being 100:22:12 and the ore composed of $84 \mathrm{wt} \%$ chromite and $16 \mathrm{wt} \%$ clinochlore).

\section{Results}

\section{Thermogravimetry and differential scanning calorimetry tests}

TG-DSC tests in the absence of a flux indicated that the first thermal event took place at approximately $700^{\circ} \mathrm{C}$, resulting in the appearance of an endotherm as well as about $3 \mathrm{wt} \%$ mass loss (Figure 1). Off-gas analysis by mass spectrometry indicated the formation of gaseous $\mathrm{H}_{2} \mathrm{O}$ from this thermal event. This is likely to be resulting from the loss of structural water from clinochlore. No appreciable amount of reduction took place before $1100^{\circ} \mathrm{C}$. The reduction rate became significant when the temperature reached $1300^{\circ} \mathrm{C}$, resulting in a rapid mass loss. The main gas product was $\mathrm{CO}$, based on the off-gas analysis. To allow for an unambiguous comparison with the other tests, the thermogravimetry (TG) curve was reprocessed by separating the two thermal events (i.e. loss of structural water and reduction), and normalizing the mass loss to represent the mass loss per $100 \mathrm{mg}$ ore. The 


\section{Influences of alkali fluxes on direct reduction of chromite for ferrochrome production}
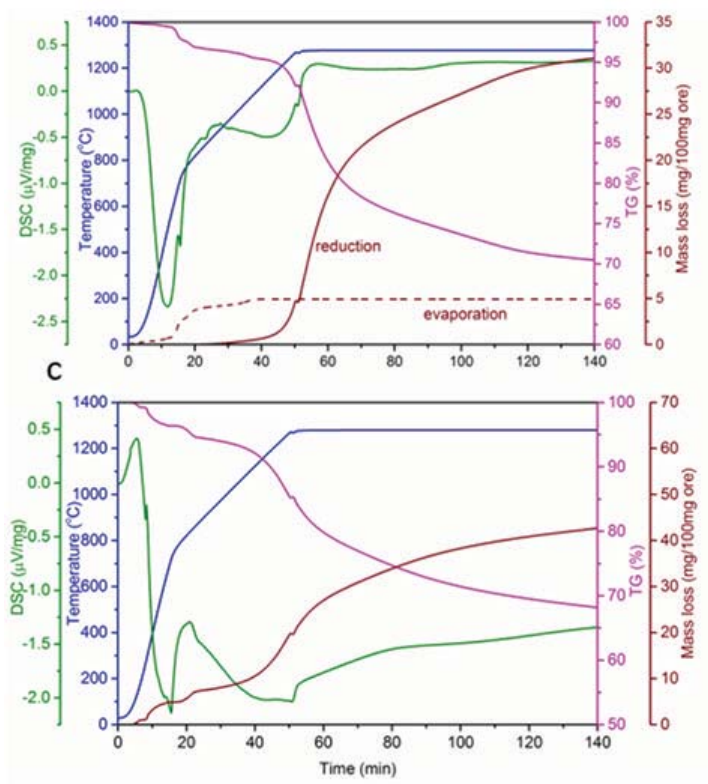

b
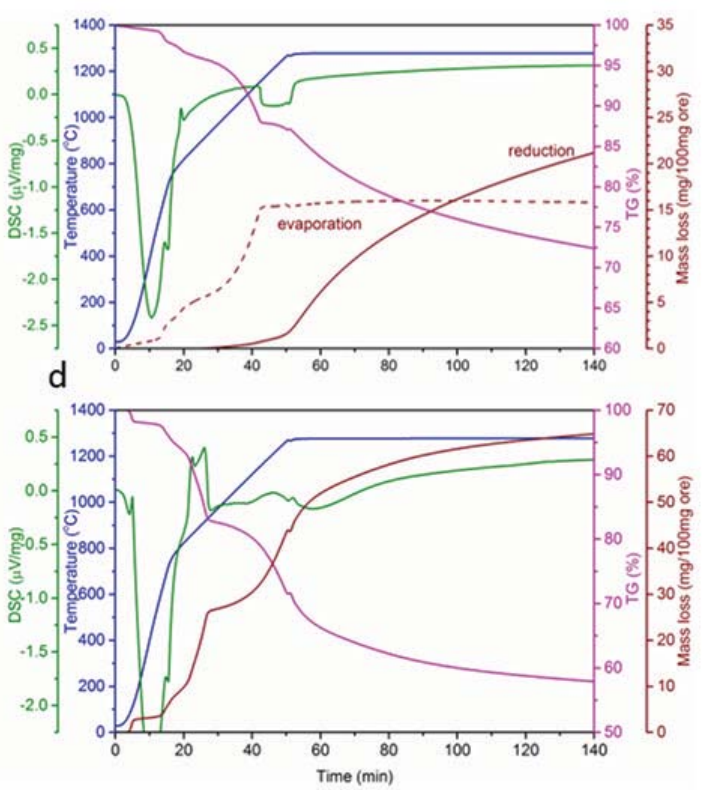

Figure 1-TG-DSC analysis of the reduction of chromite at $1300^{\circ} \mathrm{C}$ (a) without a flux, (b) with $12 \mathrm{wt} \% \mathrm{NaCl}$, (c) with $12 \mathrm{wt} \% \mathrm{NaOH}$, and (d) with 32 wt $\%$ $\mathrm{Na}_{2} \mathrm{CO}_{3}$. DSC: differential scanning calorimetry; TG: thermogravimetry

mass loss curves for both the thermal dehydration and reduction (Figure 1a) indicate that the carbothermic reduction of chromite was not complete after 2 hours of reduction.

TG-DSC test results evaluating the effect of $\mathrm{NaCl}$ addition on the carbothermic reduction are shown in Figure $1 \mathrm{~b}$. The same thermal dehydration event described earlier for the noflux case also took place in this test, as indicated by the mass loss and an endotherm at about $700^{\circ} \mathrm{C}$. A second endotherm was identified at approximately $800^{\circ} \mathrm{C}$, representing the melting of $\mathrm{NaCl}$. Significant evaporation of the molten $\mathrm{NaCl}$ took place with an increase in temperature, resulting in continuous mass loss. The evaporation of $\mathrm{NaCl}$ was complete when the temperature reached about $1150^{\circ} \mathrm{C}$, marked by the sudden change of the slope of the TG curve and a rapid decrease of the DSC signal. Based on off-gas analysis, the contributions of dehydration, evaporation of molten $\mathrm{NaCl}$, and reduction to the mass loss were evaluated. The curve representing the mass loss due to reduction was calculated by re-processing the TG curve (Figure $1 \mathrm{~b}$ ). A comparison of the results to those of the no-flux case suggests that the addition of $\mathrm{NaCl}$ inhibited the carbothermic reduction of chromite to a certain degree.

TG-DSC tests in the presence of $\mathrm{NaOH}$ produced a DSC signal that is different from the ones observed with $\mathrm{NaCl}$ and without a flux. As illustrated in Figure 1c, the first endotherm appeared at temperatures above $100^{\circ} \mathrm{C}$ with about $2 \%$ mass loss. The appearance of gaseous $\mathrm{H}_{2} \mathrm{O}$ from the off-gas analysis indicates that this thermal event is due to the evaporation of absorbed water from $\mathrm{NaOH}$. The second endotherm occurred at approximately $300^{\circ} \mathrm{C}$, resulting from the melting of $\mathrm{NaOH}$. A second stage of mass loss was observed in association with the melting of $\mathrm{NaOH}$. The increase in the $\mathrm{H}_{2} \mathrm{O}$ peak at this stage can be explained by the mass loss resulting from the decomposition of $\mathrm{NaOH}$ to $\mathrm{Na}_{2} \mathrm{O}$ and $\mathrm{H}_{2} \mathrm{O}$. The third stage of mass loss is linked with an endotherm on the DSC curve and an increase in CO in the offgas analyses that occurred at $700^{\circ} \mathrm{C}$. A reaction between $\mathrm{Na}_{2} \mathrm{O}$ and $\mathrm{C}$ forming $\mathrm{CO}$ gas (Sokhanvaran, Paktunc, and Barnes, 2018), in addition to the decomposition of clinochlore and reduction of $\mathrm{Fe}$, could be responsible for this change. Reduction reactions progressed aggressively above $1100^{\circ} \mathrm{C}$ resulting in a major mass loss (Figure 1c). Mass losses corresponding to about $38 \%$ of the ore occurred during the latter stages of the test.

The effect of $\mathrm{Na}_{2} \mathrm{CO}_{3}$ on carbothermic reduction was investigated by mixing chromite and graphite with $32 \%$ $\mathrm{Na}_{2} \mathrm{CO}_{3}$ (Figure 1d). The first thermal event occurred above $100^{\circ} \mathrm{C}$, resulting from the evaporation of absorbed water in the sample, similar to that observed in the case of $\mathrm{NaOH}$ (Figure 1c). The second endotherm appeared at $700^{\circ} \mathrm{C}$ in association with a new water peak. This phenomenon, which is similar to those observed with $\mathrm{NaCl}$ flux and with no flux (Figure $1 \mathrm{a}$ and $1 \mathrm{~b}$ ), is linked to the dehydration of clinochlore. The third endotherm on the DSC curve appeared around $800^{\circ} \mathrm{C}$. This change is probably a result of the reaction of $\mathrm{Na}_{2} \mathrm{CO}_{3}$ with $\mathrm{C}$ to form $\mathrm{CO}$ gas and $\mathrm{Na}$ vapour. Melting of $\mathrm{Na}_{2} \mathrm{CO}_{3}$ occurred at $850^{\circ} \mathrm{C}$, resulting in an increase in the rate of mass loss. Reduction of chromite occurred during the last stage, which is confirmed by the $\mathrm{CO}$ in the offgas analyses. Similar to the case with $\mathrm{NaOH}$, isolation of the different mass losses is impossible due to the interactions between carbonate and graphite. The mass loss during the final stage was about $38 \%$ of the ore, which is similar to that observed in the $\mathrm{NaOH}$ case.

\section{Carbothermic reaction products}

Representative backscattered electron photomicrographs of the products that formed after 1 hour of reduction at $1300^{\circ} \mathrm{C}$ are shown in Figure 2. The ore reduced in the presence of $\mathrm{NaCl}$ displays some similarities to that reduced with no flux. 


\section{Influences of alkali fluxes on direct reduction of chromite for ferrochrome production}

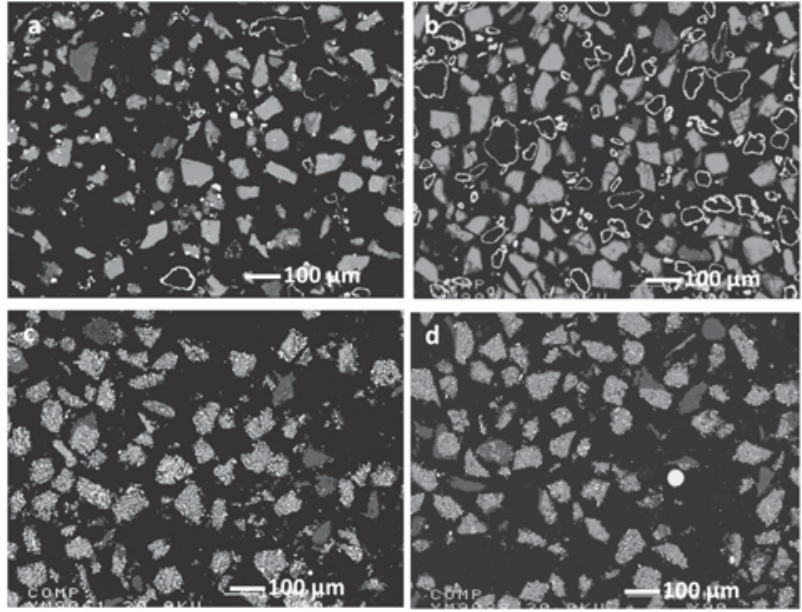

Figure 2-Backscattered electron photomicrographs of the products that formed after 1 hour of reduction at $1300^{\circ} \mathrm{C}$ (a) in the absence of a flux, (b) with $\mathrm{NaCl}$, (c) with $\mathrm{NaOH}$, and (d) with $\mathrm{Na}_{2} \mathrm{CO}_{3}$. Alloy or metal particles appear as white or very light grey, the residual chromite grains occur as light grey, and the slag as dark grey domains. Spherical white particle in (d) is an Fe-rich metal droplet measuring about $40 \mu \mathrm{m}$ across

Both are characterized by a lower degree of metallization in terms of $\mathrm{Fe}$ and $\mathrm{Cr}$ and the occurrence of alloy particles as rings on the residual graphite particles. In contrast, the products that formed in the presence of $\mathrm{NaOH}$ and $\mathrm{Na}_{2} \mathrm{CO}_{3}$ display higher degrees of metallization with increased amounts of alloy particles.

The compositions of the products as determined by powder XRD and scanning electron microscopy include chromite, graphite, and $\mathrm{Cr}$-Fe carbides in all the samples formed after 1 hour of carbothermic reaction. Forsterite $\left(\mathrm{Mg}_{2} \mathrm{SiO}_{4}\right)$ is present in the products that resulted in the presence of $\mathrm{NaCl}$ and $\mathrm{Na}_{2} \mathrm{CO}_{3}$.

Chromite grains in the original ore display zoning developed along particle margins and microfractures. The zoning is primary as observed in the original ore due to a geological event that affected the chromite deposits and the host rocks. The electron microprobe analyses indicate that the rims have much higher $\mathrm{Cr}$ contents and slightly lower $\mathrm{Mg}$ in the tetrahedral sites in comparison to the original (premetamorphic event) chromite compositions reflected by the chromite core compositions (Figure 3). The zoning, with higher $\mathrm{Cr}$ and lower $\mathrm{Al}$ in the octahedral sites and slightly increased $\mathrm{Mg}$ fractions in the tetrahedral sites, is one of the characteristics of the Ring of Fire chromite, and is believed to play an important role in the reducibility of the ores. This feature will be discussed in detail in a separate paper.

The compositions of the chromite reduced in the presence of $\mathrm{NaCl}$ after 45 minutes' reaction are similar to the original chromite compositions, indicating that very little or no detectable chemical changes occurred. The sample reduced for 60 minutes in the presence of $\mathrm{NaCl}$ displayed some changes in the chromite composition although some residual chromite particles remained intact. Compositional changes are essentially the same, limited to reduced $\mathrm{Fe}^{2+}$ contents (or increased $\mathrm{Mg}$ at the expense of $\mathrm{Fe}^{2+}$ ) due to removal of iron from the crystal structure.
The residual chromite grains in the products of the $\mathrm{NaOH}$ and $\mathrm{Na}_{2} \mathrm{CO}_{3}$ experiments have virtually no Fe remaining (Figure 3). The zoning in chromite is less apparent. The lighter grey areas in Figures $4 \mathrm{a}-\mathrm{c}$ represent residual chromite, whereas the darker grey domains represent the slag. The residual chromite grains in both cases, represented by lighter grey areas in Figures $4 \mathrm{a}-\mathrm{c}$, are depleted in Fe (both divalent and trivalent) and the $\mathrm{Cr}$ and $\mathrm{Al}$ contents are variable.

\section{Metallization and composition of alloys}

The compositions of the ferrochrome alloys formed under the influence of $\mathrm{NaCl}$ flux are shown in Figure 5. There are two compositional types: one that occurs along intergrain boundaries and crystallographic planes of the host chromite as shown in Figure 4d; and a second, which is essentially an Fe metal with minor $\mathrm{Cr}$ and carbon. The latter type is an $\mathrm{M}_{7} \mathrm{C}_{3}$ type carbide with a variable composition from $\mathrm{Cr}_{3.2} \mathrm{Fe}_{3.8} \mathrm{C}_{3}$ to $\mathrm{Cr}_{5.0} \mathrm{Fe}_{2.0} \mathrm{C}_{3}$ (Figure 5). The $\mathrm{M}_{7} \mathrm{C}_{3}$ type occurs as rings on residual graphite particles (Figure $2 b$ ).

Ferrochrome alloys formed with $\mathrm{NaOH}$ flux appear to have a tighter compositional variation along the $\mathrm{M}_{7} \mathrm{C}_{3}$ join (Figure 5). The composition is variable from $\mathrm{Cr}_{4.2} \mathrm{Fe}_{2.8} \mathrm{C}_{3}$ to $\mathrm{Cr}_{4.6} \mathrm{Fe}_{2.4} \mathrm{C}_{3}$. Ferrochrome particles in larger domains of slag tend to be coarser (Figure 4a) than those developing from within the chromite grains (Figure 4b). Another mode of occurrence of the alloy particles is in the form of blebs or metal droplets that are rich in $\mathrm{Fe}$. In the example shown in Figure $4 \mathrm{e}$, an Fe-rich $\mathrm{M}_{7} \mathrm{C}_{3}$ phase $\left(\mathrm{Cr}_{2} \mathrm{Fe}_{5} \mathrm{C}_{3}\right)$ occurs as an exsolved phase from the Fe metal.

The alloys formed in the presence of $\mathrm{Na}_{2} \mathrm{CO}_{3}$ flux have compositions variable from $\mathrm{Cr}_{3} \mathrm{Fe}_{4} \mathrm{C}_{3}$ to $\mathrm{Cr}_{4} \mathrm{Fe}_{3} \mathrm{C}_{3}$ (Figure 5). The carbide occurs along the particle rims of the residual chromite as well as developing along the crystallographic planes of the host (Figure 4c). Its occurrence is similar to that formed in the presence of $\mathrm{NaOH}$ flux (Figures $4 \mathrm{a}$ and $4 \mathrm{~b}$ ).

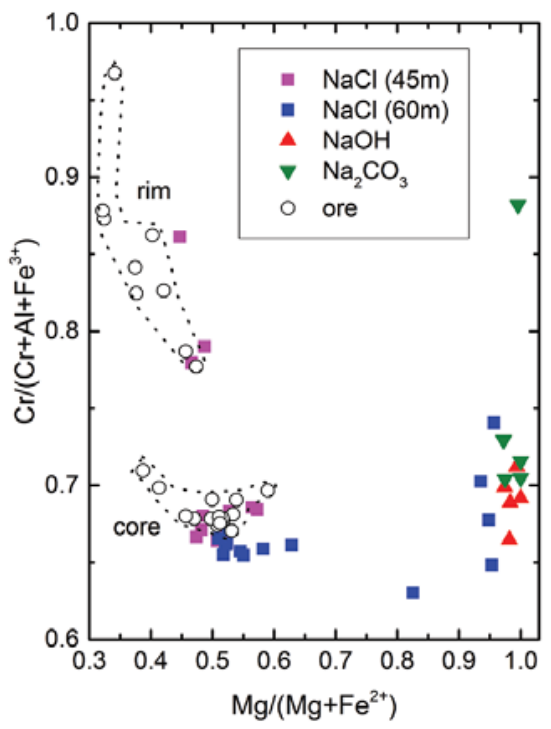

Figure 3-Electron microprobe analyses of the original and residual chromite particles in terms of cation fractions in the tetrahedral and octahedral sites of chromite. Original chromite is denoted as 'ore'. Other chromite types are residual chromite formed at $1300^{\circ} \mathrm{C}$ after 60 minutes of carbothermic reaction in the presence of $\mathrm{NaCl}, \mathrm{NaOH}$, and $\mathrm{Na}_{2} \mathrm{CO}_{3} . \mathrm{NaCl}(45 \mathrm{~m}): 45$ minutes' reaction 


\section{Influences of alkali fluxes on direct reduction of chromite for ferrochrome production}

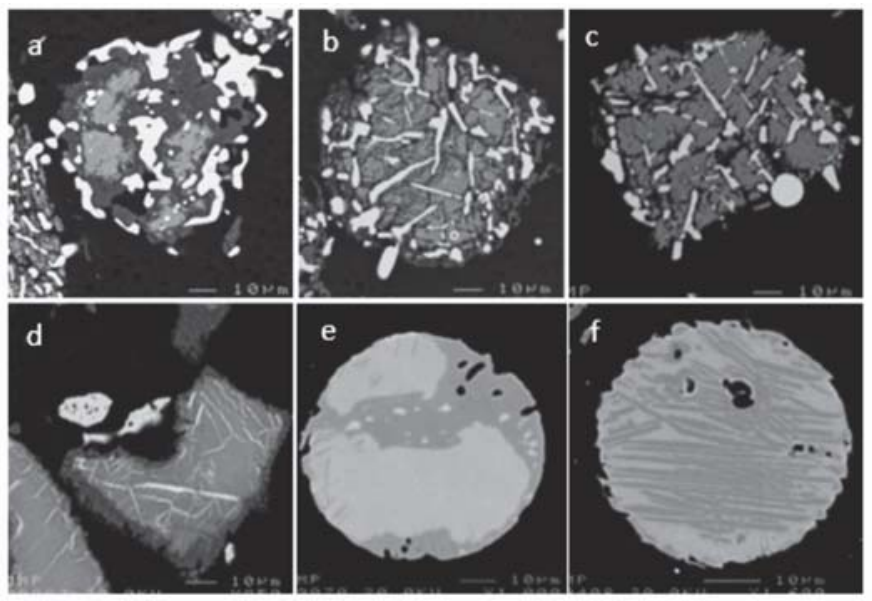

Figure 4-Backscattered electron photomicrographs of residual chromite particles in the presence of $\mathrm{NaOH}$ flux (a and b), $\mathrm{Na}_{2} \mathrm{CO}_{3}$ flux (c), and $\mathrm{NaCl}$ flux (d). Light grey areas in (a) and (b) are residual chromite, dark grey domains are slag, and white particles are alloy. Exsolution lamellae (white) in (d) are $\mathrm{Fe}_{9} \mathrm{Cr}$ formed in situ within chromite (grey). Iron melt droplets (white) with exsolved $\mathrm{Fe}_{19-21} \mathrm{Cr}_{2-4} \mathrm{C}_{6}$ (grey) formed in the presence of $\mathrm{NaOH}$ flux (e) and $\mathrm{Na}_{2} \mathrm{CO}_{3}$ flux (f). Scale bar is $10 \mu \mathrm{m}$ in all

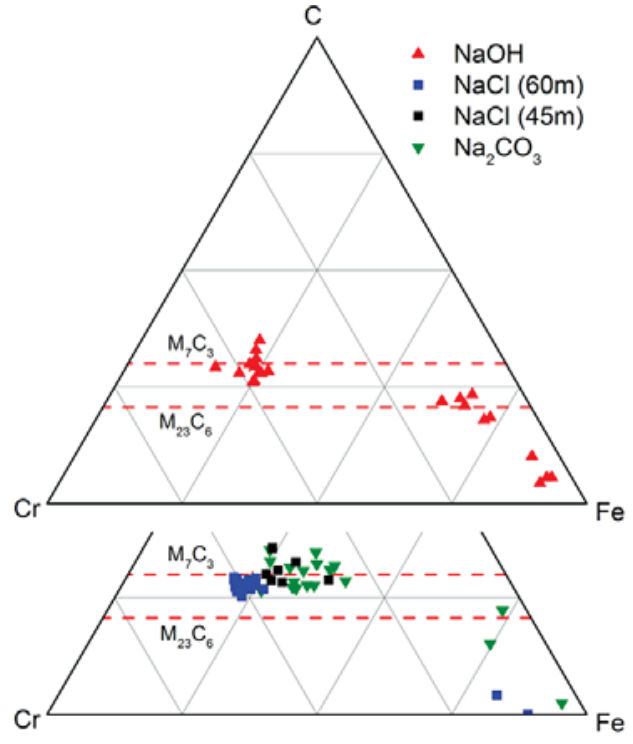

Figure 5-Composition of the metallic phases, determined by electron microprobe, formed in the presence of $\mathrm{NaOH}$ (top), and $\mathrm{NaCl}$ and $\mathrm{Na}_{2} \mathrm{CO}_{3}$ (bottom). Iron-rich particles with low $\mathrm{Cr}$ and $\mathrm{C}$ are those that formed either in situ in chromite (Figure 7d) and as melt droplets (Figures $7 \mathrm{e}$ and $7 \mathrm{f}$ ). Compositions of the $\mathrm{M}_{7} \mathrm{C}_{3}$ type carbides formed with $\mathrm{NaOH}$ can be defined as $\mathrm{Cr}_{4 \cdot 2-4.9} \mathrm{Fe}_{2.1-2.8} \mathrm{C}_{3}$, with $\mathrm{NaCl}$ flux as $\mathrm{Cr}_{3.2-5.0} \mathrm{Fe}_{2.0-3.8} \mathrm{C}_{3}$, and with $\mathrm{Na}_{2} \mathrm{CO}_{3}$ flux as $\mathrm{Cr}_{3-4} \mathrm{Fe}_{3-4} \mathrm{C}_{3} . \mathrm{NaCl}$ (45 m: 45 minutes reaction

XANES spectra collected at the $\mathrm{Cr}$ and Fe K-edges are shown in Figure 6. In terms of $\mathrm{Cr}$ reduction, least-squares fitting of the spectrum representing no-flux conditions indicates that the degree of $\mathrm{Cr}$ metallization is only $36 \%$ after 1 hour of reduction at $1300^{\circ} \mathrm{C}$, while Fe metallization is complete at $100 \%$ (Figure 6). Reduction of Fe much earlier than $\mathrm{Cr}$ is also evident from the empirical evidence shown by TGA-DSC analyses, furnace tests, and thermodynamic predictions. Addition of $\mathrm{NaCl}$ as the flux resulted in a slightly improved metallization at $45 \%$ after 1 hour of reduction. In terms of Fe reduction, addition of $\mathrm{NaCl}$ as the flux slightly degraded the metallization. The degree of metallization is $85 \%$ for $\mathrm{Cr}$ and $100 \%$ for $\mathrm{Fe}$ with the use of $\mathrm{NaOH}$ as the flux. This is significant in comparison to the degree of $\mathrm{Cr}$ metallization reached in the absence of a flux, approximately $36 \%$. A lower degree of $\mathrm{Cr}$ metallization at $66 \%$ and $100 \% \mathrm{Fe}$ metallization were achieved with $\mathrm{Na}_{2} \mathrm{CO}_{3}$ as the flux. In general, the results indicate various degrees of reduction and metallization, with $\mathrm{Fe}$ reduction always preceding that of $\mathrm{Cr}$.

\section{Slag composition}

Electron microprobe analyses indicate that the slags formed in the presence of $\mathrm{NaOH}$ and $\mathrm{Na}_{2} \mathrm{CO}_{3}$ are dominated by $\mathrm{SiO}_{2}$, $\mathrm{Al}_{2} \mathrm{O}_{3}, \mathrm{Na}_{2} \mathrm{O}$, and $\mathrm{MgO}$. In contrast, as illustrated on the $\mathrm{Na}_{2} \mathrm{O}-\mathrm{Al}_{2} \mathrm{O}_{3}-\mathrm{SiO}_{2}$ phase diagram representing $1300^{\circ} \mathrm{C}$ and $1 \mathrm{~atm}$. (Figure 7), the slag formed in the presence of $\mathrm{NaCl}$ contains very little $\mathrm{Na}$.

Slag that formed from reduction in the presence of $\mathrm{NaOH}$ is represented by material near the residual chromite particles as shown on the backscattered electron photomicrograph (Figure 7). It plots in or near the slag-liquid+NaAlO 2 field. Only a few points at the outer edges of the 'slag' plot in the slag-liquid field. Those that are away from the residual chromite, such as the one marked as ' 2 ' on the backscattered electron photomicrograph, plot in the slag-liquid field (Figure 7). The MgO content is high at $16.64 \mathrm{wt} \%$ in comparison to that near a chromite particle (4.92 wt\%). The slag contains minor amounts of $\mathrm{Cr}_{2} \mathrm{O}_{3}$ with values of $0.92 \mathrm{wt} \%$ near a residual chromite particle and $0.38 \mathrm{wt} \%$ in an isolated slag particle.

Slag formed with $\mathrm{Na}_{2} \mathrm{CO}_{3}$ displays some similarities to that with $\mathrm{NaOH}$. However, the 'slag' materials appear to have a bimodal distribution: one plotting in the $\mathrm{NaAlO}_{2}+\mathrm{NaAl}_{9} \mathrm{O}_{14}$ field and the other largely in the slag-liquid field.

\section{Speciation of chromium}

In order to understand the mechanism of $\mathrm{Cr}$ release to the molten slag, we determined the speciation of $\mathrm{Cr}$ in slag using a focused X-ray beam and confocal optics, allowing detection of emissions from small volumes of material at specified depths. One of the samples represents reduction at $1300^{\circ} \mathrm{C}$ 


\section{Influences of alkali fluxes on direct reduction of chromite for ferrochrome production}

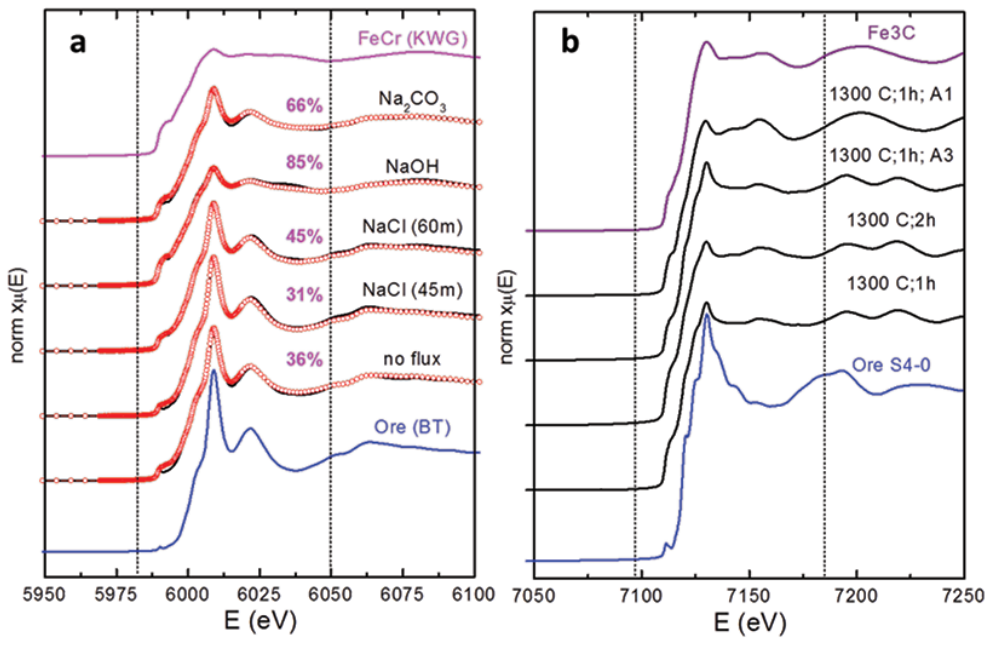

Figure 6-XANES spectra of the products formed. Normalized k3-weighted Cr K-edge spectra are on the left and Fe K-edge spectra on the right. The degrees of $\mathrm{Cr}$ metallization (left) are based on least-squares fitting of the reference spectra of ferrochrome (FeCr, in fuschia) and chromite ore (ore, in blue) in the energy range marked by vertical lines at approximately 5982 and $6050 \mathrm{eV}$. Solid black lines are experimental spectra, whereas the lines with red circles are simulated spectra

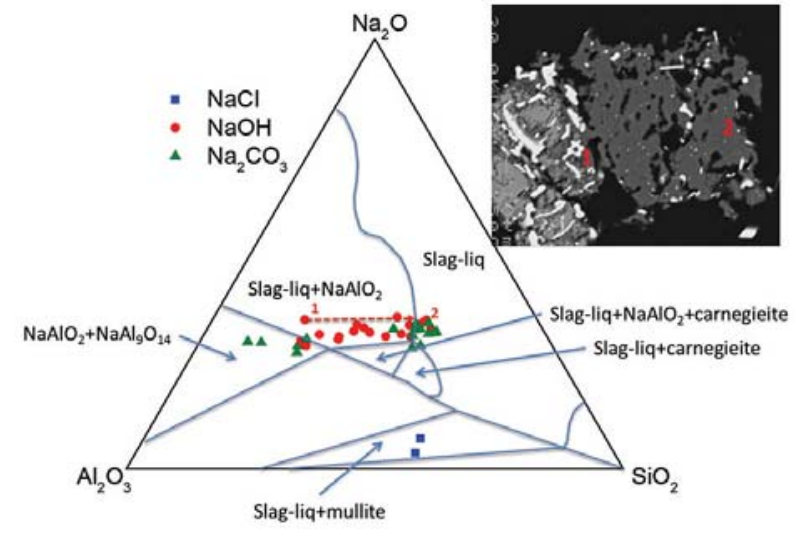

Figure $7-\mathrm{Na}_{2} \mathrm{O}-\mathrm{Al}_{2} \mathrm{O}_{3}-\mathrm{SiO}_{2}$ phase diagram representing $1300^{\circ} \mathrm{C}$ and $1 \mathrm{~atm}$. with slag compositions of the products resulting from reduction with the alkali fluxes. Slag domains are dark grey on the backscattered electron photomicrograph representing material from the $\mathrm{NaOH}$ experiment. The numbers refer to slag adjacent to the residual chromite particle (1) and slag that is at a distance (2). Carnegieite: NaAISiO ${ }_{4}$; mullite: $2 \mathrm{Al}_{2} \mathrm{O}_{3} \cdot \mathrm{SiO}_{2}$

without a flux (Figure 8). A residual chromite particle rimmed with minute Fe-rich alloy particles along the particle surface displays concentric zoning with decreased $\mathrm{Cr}$ and very low Fe in its outer zone. Micro-XANES spectra collected from these zones (labelled with '1-1' and '1-3' in Figure 8c) indicate identical $\mathrm{Cr}$ speciations that are typical of the chromite structure. Another zoned chromite particle with no Fe remaining in its outer rim (labelled ' 3 ' and ' 4 ' in Figure 8c) and adjacent to a large $\mathrm{Cr}$-rich ferrochrome alloy particle (labeled ' 2 ') is also dominated by $\mathrm{Cr} 3+$ species. In other words, $\mathrm{Cr}$ is trivalent and octahedrally coordinated to oxygen atoms across the residual chromite particle, irrespective of the zoning, and there are no intermediary species between the trivalent and zero-valent species. These results are conclusive, since the micro-XANES spectra are collected from very small volumes within the particles, and as such they are not influenced by emissions from adjacent zones.
Another sample representing reduction with $\mathrm{NaOH}$ at $1100^{\circ} \mathrm{C}$ for 1.5 hours was studied with the aim of determining $\mathrm{Cr}$ speciation of the slag, which is dominated by $\mathrm{Na}(\mathrm{Cr}, \mathrm{Al}, \mathrm{Fe}) \mathrm{O}_{2}$. Based on electron microprobe analyses of 15 grains, its composition can be defined as $\mathrm{Na}_{0.9-1.2} \mathrm{Cr}_{0.2}$ ${ }_{0.5} \mathrm{Al}_{0.3-0.5} \mathrm{Fe}_{0.0-0.3} \mathrm{O}_{2}$. It occurs with a $\mathrm{Na}-\mathrm{Mg}$ - $\mathrm{Al}$ silicate and residual chromite, which is $\mathrm{MgCr}_{1.4} \mathrm{Al}_{0.6} \mathrm{O}_{4}$ and similar to the species illustrated in Figure 3. Micro-XANES spectra from the slag indicate that $\mathrm{Cr}$ occurs as trivalent species and that it is octahedrally coordinated to oxygen (Figure 9).

\section{Beneficiation and recovery of ferrochrome alloys}

Equally important in the direct reduction process are the physical separation and recovery of ferrochrome particles from the slag. This requires that the ferrochrome particles are coarse and that they are liberated when ground to a particle size range that is suitable for conventional gravity and/or magnetic mineral processing techniques.

The distribution of the ferrochrome particles and their degree of liberation were determined by automated mineralogy techniques, in which the particles are identified chemically and their quantities along with their liberation are measured. Shown in Figure 10 are backscattered electron images of the particles and their colour-coded representation. These are particles formed after 1 hour of direct reduction with $\mathrm{NaOH}$ at $1300^{\circ} \mathrm{C}$. In general, the ferrochrome alloy particles are smaller than $20 \mu \mathrm{m}$. It appears that the ferrochrome alloy particles tend to occur as larger particles, around $20 \mu \mathrm{m}$ in size, where the associated slag phase is coarse.

Between 20000 and 30000 such particles were measured by the quantitative or automated mineralogy technique (Figure 11). In the case of $\mathrm{NaOH}$ flux, ferrochrome alloy particles constitute about $26 \%$ by volume of the total particles. The slag constitutes about $50 \%$, and the residual chromite $22 \%$. The amount of ferrochrome particles is significantly underestimated because the spatial resolution of the technique is limited in detecting and counting small 

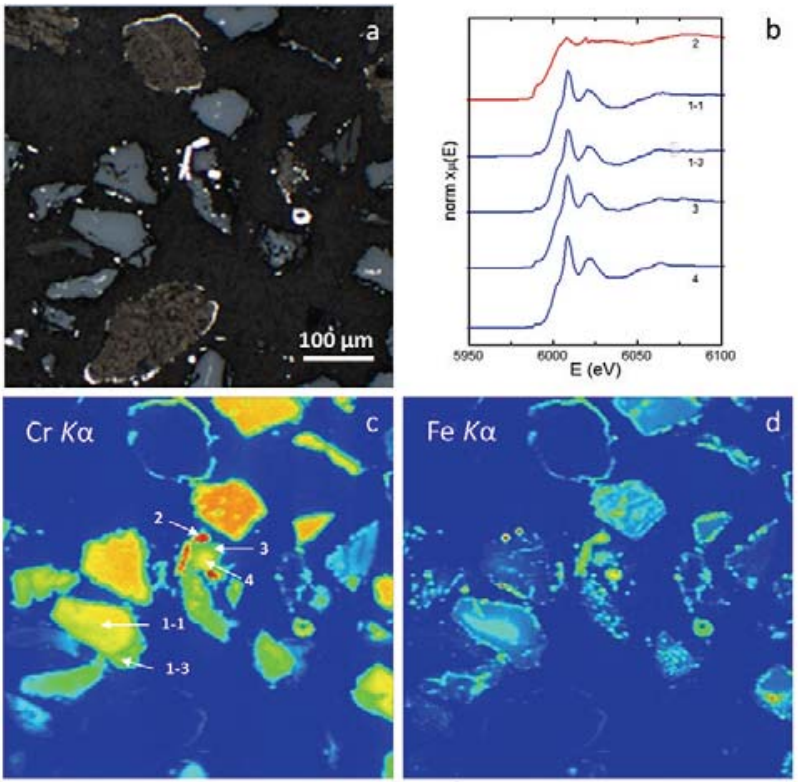

Figure 8-Backscattered electron image of (a) normalized $\mathbf{k}^{3}$-weighted Cr K-edge micro-XANES spectra from locations shown in (c), and (b) corresponding micro-X-ray fluorescence maps of $\mathrm{Cr}$ (c) and $\mathrm{Fe}$ (d) of the sample reduced at $1300^{\circ} \mathrm{C}$ for 1 hour without a flux. The maps represent several micrometer-thick sections, collected using microchannel confocal optics and show the locations of micro-XANES spectra

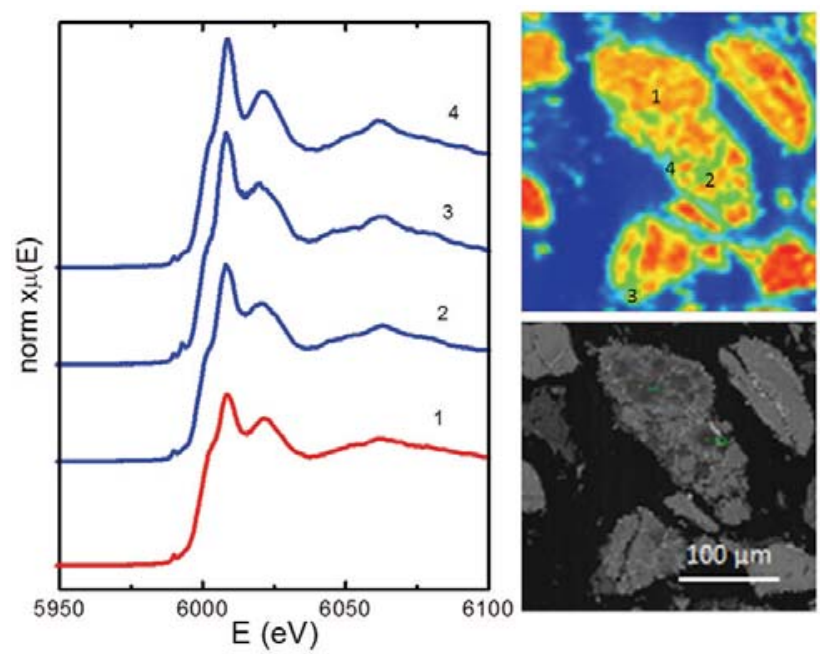

Figure 9-Normalized $\mathbf{k}^{3}$-weighted $\mathrm{Cr} \mathrm{K}$-edge micro-XANES spectra of residual chromite (no. 1 in red) and slag (nos. 2-4 in blue) resulting from direct reduction with $\mathrm{NaOH}$ at $1100^{\circ} \mathrm{C}$ for 1.5 hours. The map on the upper right represents $\mathrm{Cr}$ Ka micro-X-ray fluorescence showing the locations of the micro-XANES spectra, and the lower right is a backscattered electron photomicrograph of the same area.

(1): $\mathrm{NaAl}_{0.40-0.45} \mathrm{Cr}_{0.35-0.40} \mathrm{Fe}_{0.2} \mathrm{O}_{2}$; (2), (3), and (4):

$\mathrm{NaAl}_{0.7} \mathrm{Cr}_{0.1} \mathrm{Fe}_{0.1} \mathrm{O}_{2}+\mathrm{SiO}_{2}$

ferrochrome particles. The ferrochrome particles are largely unliberated or locked with the residual chromite and gangue particles. The degree of liberation clusters around the 20$40 \%$ range. This suggests that the liberation of ferrochrome at a coarse grind will be challenging and that the recovery of ferrochrome by conventional gravity and magnetic separation techniques would be limited.
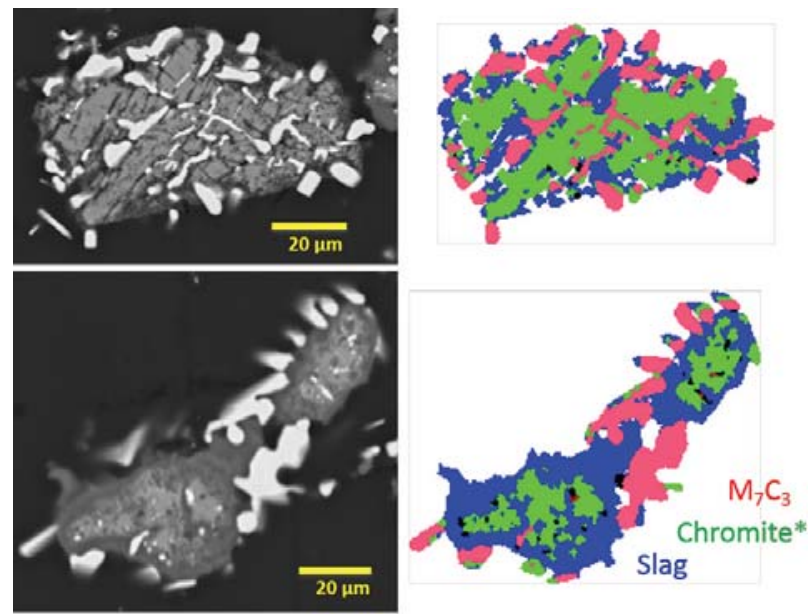

Figure 10-Backscattered electron images of reduced particles in the presence of $\mathrm{NaOH}$ and corresponding colour-coded drawings outlining individual phases measured by automated mineralogy. Composition of the residual chromite is different from that of the chromite in the original ore
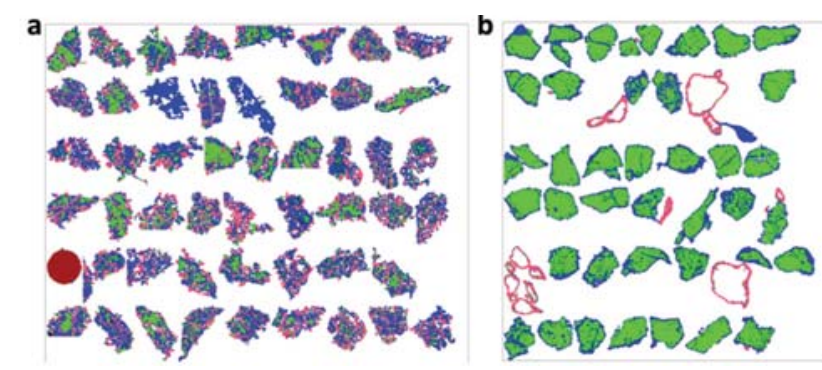

Figure 11-Distribution of alloy, slag, and residual chromite particles in the product formed from direct reduction in the presence of (a) $\mathrm{NaOH}$ and (b) $\mathrm{NaCl} . \mathrm{M}_{7} \mathrm{C}_{3}$ : pink; iron metal: red; slag: blue; residual chromite: green

As illustrated in Figure 11, the size of ferrochrome particles formed in the presence of $\mathrm{NaCl}$ is too small, suggesting that the degree of liberation would be less than satisfactory for typical mineral processing circuits. This is much improved in the case of $\mathrm{NaOH}$-assisted reduction; however, the alloy particles are rather small. The particles are dominated by residual chromite, with much lower amounts of alloy and slag particles. These are detrimental to effective beneficiation of the alloy particles in the examples provided in this study.

\section{Discussion}

Alkali-assisted direct reduction of chromite results in various degrees of reduction and metallization, with Fe reduction always preceding that of $\mathrm{Cr}$. In comparison to the $36 \% \mathrm{Cr}$ metallization with no flux at $1300^{\circ} \mathrm{C}$ after 1 hour, it appears that $\mathrm{NaCl}$ addition slightly improved the $\mathrm{Cr}$ metallization to $45 \%$. The degree of $\mathrm{Cr}$ metallization reached to $85 \%$ with the use of $\mathrm{NaOH}$, and $66 \%$ with $\mathrm{Na}_{2} \mathrm{CO}_{3}$ as the flux.

It appears that the reduction and metallization of $\mathrm{Cr}$ and Fe species are localized along grain boundaries, microfractures, cleavage planes, and imperfections within chromite particles (Figure 4a-4d). With continued reduction, 


\section{Influences of alkali fluxes on direct reduction of chromite for ferrochrome production}

Fe-rich Fe-Cr melt pools and segregates into larger immiscible liquid patches (Figures $2 \mathrm{~d}, 4 \mathrm{c}, 4 \mathrm{e}$, and 4f). Intricate spatial relationships among the alloy, residual chromite, and slag particles suggest that Fe is reduced in situ by $\mathrm{CO}$ whereas $\mathrm{Cr}$ is reduced on solid carbon particles. The alloys in the final product of $\mathrm{NaOH}$ reduction $\left(\mathrm{Cr}_{4.2-4.6} \mathrm{Fe}_{2.4-2.8} \mathrm{C}_{3}\right)$ are at a slightly lower degree of $\mathrm{Cr}$ metallization in comparison to the predicted alloy composition at equilibrium $\left(\mathrm{Cr}_{4.8} \mathrm{Fe}_{2.2} \mathrm{C}_{3}\right)$. In terms of $\mathrm{Cr}$ content, the individual alloy particles represent variable degrees of metallization, from 87.0 to $95.7 \%$ of the equilibrium value. These values are slightly higher than the observed degree of metallization, which is $85 \%$ based on the bulk XANES spectra of the final product. This discrepancy is reasonable considering the limited number of alloy particles analysed by electron microprobe and the uncertainty in the least-squares fitting of the XANES spectrum, which is about $5 \%$. In the case of $\mathrm{Na}_{2} \mathrm{CO}_{3}$, compositions of the alloy particles, which are variable from $\mathrm{Cr}_{3} \mathrm{Fe}_{4} \mathrm{C}_{3}$ to $\mathrm{Cr}_{4} \mathrm{Fe}_{3} \mathrm{C}_{3}$ are indicative of Cr metallization varying from 61.5 to $82.7 \%$, covering the observed degree of metallization at $66 \%$. TGA measurements indicate mass losses of about $63 \%$ of the ore after 2 hours of reduction with $32 \% \mathrm{Na}_{2} \mathrm{CO}_{3}$. When compared to the mass loss of about $41 \%$ with $12 \% \mathrm{NaOH}$, these observations suggest that more $\mathrm{Na}_{2} \mathrm{CO}_{3}$ would be needed as the flux to achieve a similar degree of reduction as with $\mathrm{NaOH}$. In addition, the $\mathrm{CO}_{2}$ released from the decomposition of $\mathrm{Na}_{2} \mathrm{CO}_{3}$ would further retard the reduction. The compositions of the $\mathrm{M}_{7} \mathrm{C}_{3}$ type alloy particles formed under the influence of $\mathrm{NaCl}\left(\mathrm{Cr}_{3.2-5.0} \mathrm{Fe}_{2.0}\right.$ ${ }_{3.8} \mathrm{C}_{3}$ ) indicate variable degrees of metallization in the 65.7 to $104.4 \%$ range, deviating from the equilibrium value. These numbers suggest non-equilibrium compositions for the alloy particles nucleated on graphite.

The products formed at $1300^{\circ} \mathrm{C}$ after 1 hour with $\mathrm{NaCl}$ flux are composed of chromite, graphite, $\mathrm{Cr}$-Fe carbide, and olivine and are similar to those formed with no flux. At equilibrium, the quantities of alloy, spinel, and graphite forming at the temperature range of $800-1400^{\circ} \mathrm{C}$ in the presence of $\mathrm{NaCl}$ flux are similar to those formed without a flux (Figure 12a). Olivine contents forming at 800, 900, 1200,1300 , and $1400^{\circ} \mathrm{C}$ are also similar. The only
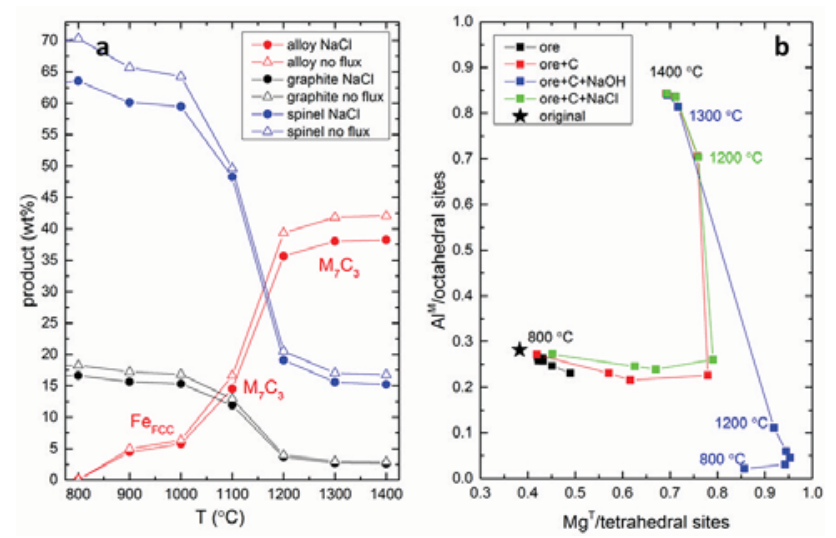

Figure 12-Thermodynamics of $\mathrm{NaCl}$-assisted direct reduction during carbothermic reactions. (a) Equilibrium concentrations of chromite, graphite, and metallic phases predicted to form at 800 to $1400^{\circ} \mathrm{C}$; (b) equilibrium partitioning of cations in the spinel structure at temperatures of 800 to $1400^{\circ} \mathrm{C}$. 'Original': starting composition of chromite in ore differences are in the Al-Si phases, which are cordierite $\left(\mathrm{Mg}_{2} \mathrm{Al}_{4} \mathrm{Si}_{5} \mathrm{O}_{18}\right)$ and slag-liquid in the case of no flux and nepheline $\left(\mathrm{NaAlSiO}_{4}\right)$, feldspar $\left(\mathrm{NaAlSi}_{3} \mathrm{O}_{8}\right)$, and slag-liquid in the case of $\mathrm{NaCl}$ flux. It appears that at low temperatures, there is little or no reaction between $\mathrm{NaCl}$ and chromite. The reaction products include nepheline, feldspar, and slag-liquid, some of which may have formed from the reactions with the gangue. The thermodynamics are in essence identical and $\mathrm{NaCl}$ has little influence on reduction and metallization.

In the presence of $\mathrm{NaCl}$ flux, predicted chromite compositions evolved, in part, towards increased $\mathrm{Mg}$ through the loss of Fe from the crystal structure, with little change in terms of the proportions of trivalent cations (Figure 3). In this case, with continued reduction $\mathrm{Fe}^{2+}$ would diffuse out towards the particle margins or reaction front. It is also possible that the $\mathrm{Fe}^{2+}$ ions are substituted by $\mathrm{Mg}$ released to the melt from the dissolution of clinochlore. The changes in the chromite composition were limited and occurred only after 1 hour of reduction, providing significant kinetic limitations to the reactions in accordance with the TGA results. In contrast, such changes in the residual chromite compositions were complete in the presence of $\mathrm{NaOH}$ and $\mathrm{Na}_{2} \mathrm{CO}_{3}$ fluxes. At equilibrium, the changes in the chromite composition are limited to increases in $\mathrm{Mg}$ due to reduction of $\mathrm{Fe}$ in the tetrahedral sites until $1100^{\circ} \mathrm{C}$ for the $\mathrm{NaCl}$-assisted reduction (Figure 12b). Significant changes are predicted to occur in octahedral site occupancies above $1100^{\circ} \mathrm{C}$. The mole fraction of $\mathrm{Al}$ increases by about $45 \%$ from 1100 to $1200^{\circ} \mathrm{C}$ (Figure $12 \mathrm{~b}$ ). This occurs at the expense of $\mathrm{Cr}$ in the octahedral sites, indicating significant $\mathrm{Cr}$ releases from the chromite structure in this temperature range. These cation distributions in chromite are similar to those occurring with no flux between 800 to $1400^{\circ} \mathrm{C}$ (Figure $12 \mathrm{~b}$ ). However, this does not necessarily mean that $\mathrm{NaCl}$ has no influence in accelerating the carbothermic reactions.

Our experimental findings and observations indicate that the role of $\mathrm{NaCl}$ in slag formation was also limited, likely due to its beginning to volatilize at around $1150^{\circ} \mathrm{C}$. The TGA results indicate that $\mathrm{NaCl}$ melts around $800^{\circ} \mathrm{C}$ and evaporates at approximately $1150^{\circ} \mathrm{C}$, which is in accordance with the empirical data (i.e. melting point being approx. $801^{\circ} \mathrm{C}$ and boiling point $1465^{\circ} \mathrm{C}$ ) (Haynes, 2011). Furthermore, the $\mathrm{NaCl}$ slag has much higher MgO concentrations, at 29.4 and 33.2 wt $\%$, and $\mathrm{Cr}_{2} \mathrm{O}_{3}$ concentrations at 6.2 and $13.7 \mathrm{wt} \%$. Thermodynamic predictions indicate that the amount of liquid slag forming is very low, even at $1400^{\circ} \mathrm{C}$. This would make $\mathrm{NaCl}$ not desirable as a flux. As discussed in our earlier publications, an effective accelerant must have a boiling point that is much higher and melting point that is lower than $1300^{\circ} \mathrm{C}$, the optimum direct reduction temperature (Sokhanvaran and Paktunc, 2017a; Sokhanvaran, Paktunc, and Barnes, 2018; Yu and Paktunc, 2017, 2018a, 2018b).

The quantities of the main products forming at equilibrium in the presence of $\mathrm{NaOH}$ are shown in Figure $13 \mathrm{a}$ for the temperature range of $800-1400^{\circ} \mathrm{C}$. The amounts of graphite remaining across the $800-1100^{\circ} \mathrm{C}$ range are relatively uniform, with a gradual decrease from about 14 to $13 \mathrm{wt} \%$ as the temperature increases. Across this temperature interval, the alloy is fcc-type Fe, increasing gradually in response to decreases of reductant. The amount of chromite/spinel remaining in the product across this 


\section{Influences of alkali fluxes on direct reduction of chromite for ferrochrome production}
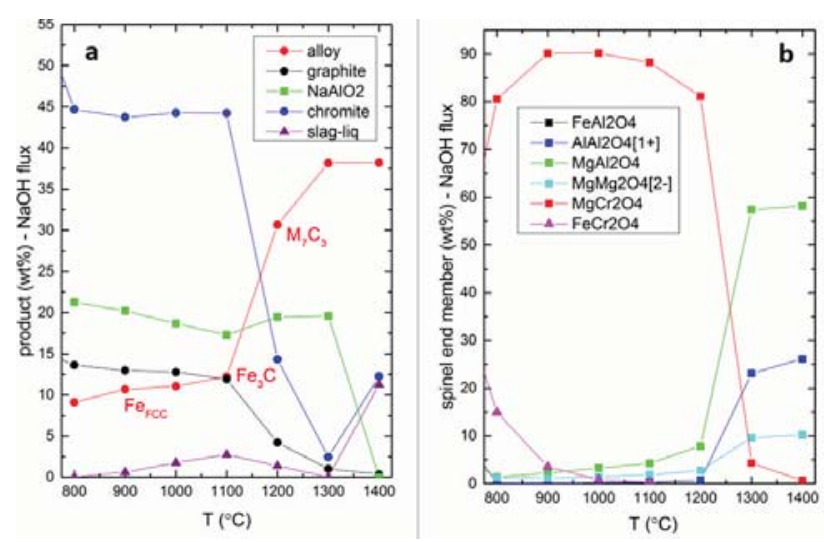

Figure 13-Thermodynamics of reduction aided by $\mathrm{NaOH}$. (a) Equilibrium concentrations of chromite/spinel, graphite, metallic phases, $\mathrm{NaAlO}_{2}$ phase, and slag-liquid predicted to form at 800 to $1400^{\circ} \mathrm{C}$; (b) mass proportions of spinel end-members at temperatures of 800 to $1400^{\circ} \mathrm{C}$ under equilibrium

temperature interval is also uniform at about $45 \mathrm{wt} \%$. Significant changes occur from 1100 to $1200^{\circ} \mathrm{C}$, including a drastic decrease in the chromite/spinel content by about $30 \mathrm{wt} \%$. Accompanying this change is the formation of $\mathrm{M}_{7} \mathrm{C}_{3}$ type carbide, reaching to about $32 \mathrm{wt} \%$, and a sudden drop in the graphite content by about $8 \mathrm{wt} \%$. This indicates that significant $\mathrm{Cr}$ reduction and metallization occur between 1100 and $1200^{\circ} \mathrm{C}$. As chromite rapidly decomposes and is reduced by graphite, $\mathrm{M}_{7} \mathrm{C}_{3}$ alloy forms. At $1300^{\circ} \mathrm{C}$, chromite is largely reduced to about $2 \mathrm{wt} \%$. Another important compound forming in the case of direct reduction with $\mathrm{NaOH}$ is $\mathrm{NaAlO}_{2}$. This phase is stable, and relatively abundant at about $20 \mathrm{wt} \%$ across the temperature interval of $800-1300^{\circ} \mathrm{C}$ (Figure 13a). $\mathrm{NaAlO}_{2}$ is present as $\mathrm{Na}_{0.9-1.2} \mathrm{Cr}_{0.2-0.5} \mathrm{Al}_{0.3}$ ${ }_{0.5} \mathrm{Fe}_{0.0-0.3} \mathrm{O}_{2}$ in the product formed at $1100^{\circ} \mathrm{C}$. The source of $\mathrm{Al}$ in this case is the chromite, as discussed below. The product formed at $1300^{\circ} \mathrm{C}$ is composed of chromite, graphite, $\mathrm{M}_{7} \mathrm{C}_{3}$ type carbide, and a $\mathrm{Na}-\mathrm{Al}$ silicate.

Thermodynamic simulations indicate that between 800 and $1200^{\circ} \mathrm{C}$, the dominant chromite/spinel end-member is magnesiochromite $\left(\mathrm{MgCr}_{2} \mathrm{O}_{4}\right)$, which is present at $80 \mathrm{wt} \%$ and higher (Figure 13b). Overall, chromite/spinel is depleted in Al. Thermodynamic simulations predict the formation of $\mathrm{NaAlO}_{2}$ across this temperature range, including $1300^{\circ} \mathrm{C}$. A small amount of Fe substitutes for $\mathrm{Al}$ in the structure. The presence of $\mathrm{NaAlO}_{2}$ in the experimental products formed at $1100^{\circ} \mathrm{C}$ is confirmed by electron microprobe analyses and Xray diffraction analyses. Its composition can be formulated as $\mathrm{NaAl}_{0.40-0.45} \mathrm{Cr}_{0.35-0.40} \mathrm{Fe}_{0.2} \mathrm{O}_{2}$. This phase has a layered structure with edge-sharing $\mathrm{Al}$ (and/or $\mathrm{Cr}$ and $\mathrm{Fe}$ ) octahedra alternating with the close-packed $\mathrm{Na}$ octahedra in an edgesharing form. These observations suggest that $\mathrm{NaOH}$ reacts with chromite to form $\mathrm{NaAlO}_{2}$ and magnesiochromite across this temperature range. At $1200^{\circ} \mathrm{C}$, the chromite composition is $\left(\mathrm{Mg}_{0.9} \mathrm{Al}_{0.1}\right)\left(\mathrm{Cr}_{1.7} \mathrm{Al}_{0.2} \mathrm{Mg}_{0.1}\right) \mathrm{O}_{4}$, becoming

$\left(\mathrm{Mg}_{0.7} \mathrm{Al}_{0.3}\right)\left(\mathrm{Cr}_{0.1} \mathrm{Al}_{1.6} \mathrm{Mg}_{0.3}\right) \mathrm{O}_{4}$ at $1300^{\circ} \mathrm{C}$. Essentially no reduction of $\mathrm{Cr}$ species occurs until $1100^{\circ} \mathrm{C}$, and $\mathrm{Cr}$ is retained in the chromite (Figure 13b). Simulations indicate that $\mathrm{NaAlO}_{2}$ becomes unstable after $1300^{\circ} \mathrm{C}$. Following its decomposition and with the release of $\mathrm{Al}$, the refractory spinel $\left(\mathrm{Mg}_{0.7} \mathrm{Al}_{0.3}\right)\left(\mathrm{Al}_{1.7} \mathrm{Mg}_{0.3}\right) \mathrm{O}_{4}$ forms at $1400^{\circ} \mathrm{C}$.

It appears that the amount of $\mathrm{Al}_{2} \mathrm{O}_{3}$ released from the chromite is limiting the formation of slag liquid through the formation of $\mathrm{NaAlO}_{2}$. The $\mathrm{Cr}$ species in the slag, which is dominated by $\mathrm{Na}(\mathrm{Cr}, \mathrm{Al}, \mathrm{Fe}) \mathrm{O}_{2}$, is trivalent, occurring in sixfold coordination to oxygen (Figure 9). This suggests that $\mathrm{Cr}$ is transported as small polymeric species in the molten/liquid slag. This highlights the importance of $\mathrm{NaAlO}_{2}$ in limiting the formation of slag-liquid and the transport of $\mathrm{Cr}$ species. This is analogous to our findings for $\mathrm{CaCl}_{2}$ (Yu and Paktunc, 2017, 2018a, 2018b) and waste material (Sokhanvaran and Paktunc 2017) in that the formation of a molten medium in the temperature range $800-1400^{\circ} \mathrm{C}$ is crucial for effective collection and reduction of the $\mathrm{Cr}$ and Fe species. It is predicted that the amount of slag-liquid forming at 800 $1300^{\circ} \mathrm{C}$ under equilibrium conditions is very low, not exceeding $2.7 \mathrm{wt} \%$. This increases to $11.3 \mathrm{wt} \%$ at $1400^{\circ} \mathrm{C}$, suggesting that $\mathrm{NaOH}$-assisted direct reduction would require temperatures higher than $1300^{\circ} \mathrm{C}$. For an effective reduction and segregation of ferrochrome from the residual slag, as in the case of $\mathrm{CaCl}_{2}$-assisted direct reduction (Yu and Paktunc, 2018a, 2018b), the reducible cations (i.e. $\mathrm{Cr}^{3}+$ and $\mathrm{Fe}^{2+}$ ) should be transported as ionic species in the form of monomers, dimers, or small oligomeric species in molten media or a gas phase and reduced on carbon particles.

\section{Conclusions}

Direct reduction of chromite ore with alkali fluxes at $1300^{\circ} \mathrm{C}$ for 1 hour produced $(\mathrm{Cr}, \mathrm{Fe}){ }_{7} \mathrm{C}_{3}$ type alloys with $\mathrm{Cr} / \mathrm{Fe}$ mass ratios variable from 0.7 to 2.3. Among the alkali fluxes, $\mathrm{NaCl}$ resulted in a low degree of $\mathrm{Cr}$ metallization, at $45 \%$. This is largely due to evaporation of $\mathrm{NaCl}$ at around $1150^{\circ} \mathrm{C}$. Reduction with $\mathrm{Na}_{2} \mathrm{CO}_{3}$ resulted in $66 \% \mathrm{Cr}$ metallization. $\mathrm{NaOH}$ caused a much higher degree of $\mathrm{Cr}$ metallization, reaching $85 \%$ with the ferrochrome alloy being $\mathrm{Cr}_{4.2-4.6}$ $\mathrm{Fe}_{2.4-2.8} \mathrm{C}_{3}$ and having a $\mathrm{Cr} / \mathrm{Fe}$ mass ratio of 1.4-1.8.

Metallization is facilitated by the formation of liquid slag in the presence of $\mathrm{Na}_{2} \mathrm{O}$ and $\mathrm{Al}_{2} \mathrm{O}_{3}$. The $\mathrm{Cr}$ and $\mathrm{Fe}$ oxides are transported in the liquid slag as ionic species to the reduction sites on solid carbon particles. The details of the reaction mechanism will be presented in a separate paper. Across the temperature range of $800-1200^{\circ} \mathrm{C}, \mathrm{NaOH}$ reacts with chromite to form $\mathrm{NaAlO}_{2}$ and magnesiochromite, which is $\left(\mathrm{Mg}_{0.9} \mathrm{Al}_{0.1}\right)\left(\mathrm{Cr}_{1.7} \mathrm{Al}_{0.2} \mathrm{Mg}_{0.1}\right) \mathrm{O}_{4}$ at $1200^{\circ} \mathrm{C}$. Magnesiochromite becomes unstable at $1300^{\circ} \mathrm{C}$, resulting in the release of $\mathrm{Cr}$. However, $\mathrm{NaAlO}_{2}$ is still stable, which limits the formation of liquid slag. This is detrimental to collecting and transporting the charged octahedral $\mathrm{CrO}_{6}$ species in molten media to graphite particles. Following the decomposition of $\mathrm{NaAlO}_{2}$ above $1300^{\circ} \mathrm{C}$, the amount of liquid slag increases to about $12 \mathrm{wt} \%$ at $1400^{\circ} \mathrm{C}$ and a refractory $\mathrm{Mg}$-Al spinel forms.

Ferrochrome particles formed under the limited experimental conditions studied in this paper at $1300^{\circ} \mathrm{C}$ and lower are small and largely unliberated. This would make the recovery of ferrochrome by conventional gravity and magnetic separation techniques difficult. It appears that the $\mathrm{NaOH}$-assisted direct reduction and alloy growth would require reduction temperatures greater than $1300^{\circ} \mathrm{C}$ and effective transport of reducible cations in a molten medium or gas phase to carbon particles. 


\section{Influences of alkali fluxes on direct reduction of chromite for ferrochrome production}

With a degree of metallization of $85 \%$, direct reduction of chromite aided by $\mathrm{NaOH}$ is promising as an alternative technology to conventional smelting in electric arc furnaces or as a prereduction technology prior to conventional smelting. Based on our extensive review of furnaces used for direct reduction of iron and the work of Sokhanvaran, Paktunc, and Barnes (2018), it is envisaged that rotary kiln- and rotating hearth-type furnaces would be potentially suitable for direct reduction of chromite. There is the potential for the formation of $\mathrm{Cr} 6+$ in the presence of excess oxygen during reduction. This and other waste management issues related to direct reduction of chromite are being investigated.

\section{Acknowledgements}

The contributions of the following are acknowledged: Derek Smith, Judith Price, Kevin Ferris, and Elizabeth Houghton for help with sample preparation, laboratory tests, and analytical work, KWG Resources for providing ore samples, and XPS for performing some of the furnace tests and TGA-DSC analyses. Constructive comments from two anonymous journal referees are acknowledged. X-ray absorption spectroscopy experiments were performed at the PNC-CAT beamline, Advanced Photon Source, Argonne National Laboratory, which is supported by the US Department of Energy under Contracts W-31-109-Eng-38 (APS) and DE-FG0397ER45628 (PNC-CAT) through a General User Proposal to the lead author and a Partnership Proposal funded by the Natural Sciences and Engineering Research Council of Canada through a major facilities access grant to the Canadian Light Source. The study was funded by NRCan under the Rare Earth Elements and Chromite R\&D Program.

\section{References}

Barnes, A., Muinonen, M., and Lavigne, M.J. 2015. Reducing energy consumption by alternative processing routes to produce ferrochromium alloys from chromite ore. Proceedings of the Conference of Metallurgists, Annual Meeting, COM' 2015. CIM, Montreal. 22 pp.

BeuKes, J.P., VAn ZyL, P.G., and NeIZEL, B.W. 2015. Process for enhanced prereduction of chromite. Patent WO2015015250 A1.

DAWSON, N.F. and EDWARDS, R.I. 1986. Factors affecting the reduction rate of chromite. INFACON 86: Proceedings of the 4th International Ferro-alloys Congress, Rio de Janeiro, Brazil, 31 August - 3 September.

Finardi, J., Nascimento; J.O., and Homem de Melo, F.D. (eds.). Associacao Brasileira dos Produtores de Ferro-Ligas-Abrafe, Sao Paulo. pp.105-113.

HAYnes, W.M. 2011. CRC Handbook of Chemistry and Physics (92nd ed.). CRC PRESS. ISBN 978-1439855119HAYNES, W.M. 2014. CRC Handbook of Chemistry and Physics. 94th edn. CRC Press, Boca Raton, FL. pp. 4-89

International Chromium Development Association. 2016. Life cycle inventory (LCI) of primary ferrochrome production 2012. Final Report. 48 pp.

Katayama, H.G., Tokuda, M., and Ohtani, M. 1986. Promotion of the carbothermic reduction of chromium ore by the addition of borates. Transactions of the Iron and Steel Institute of Japan, vol. 22, no. 10. pp. 1513-1520.

LEKATOU, A. and WALKER, R.D. 1997. Effect of $\mathrm{SiO}_{2}$ addition on solid state reduction of chromite concentrate. Ironmaking \& Steelmaking, vol. 24. pp. 133-143.

Mccullough, S., Hockaday, S., Johnson, C., and BARcZA, N.A. 2010. Prereduction and smelting characteristics of Kazakhstan ore samples. INFACON 2010: Proceedings of the12th International Ferroalloys Congress: Sustainable Future, Helsinki, Finland, 6-9 June. Vartiainen, A. (ed.). Outotec Oyj. pp. 249-262.

NAIKER, O. 2007. The development and advantages of Xstrata's Premus process. INFACON XI: Proceedings of the 11th International Ferroalloys Congress: Innovation in Ferroalloy Industry, New Delhi, India, 18-21
February. Indian Ferro Alloy Producers Association. pp. 112-119. NAIKER, O. and RiLEY, T. 2006. Xstrata Alloys in profile. Proceedings of Southern African Pyrometallurgy, Johannesburg, South Africa. Jones, R.T. (ed.). Southern African Institute of Mining and Metallurgy, Johannesburg pp. 297-306.

Neizel, B.W., BeuKes, J.P., VAn ZyL, P.G., and Dawson, N.F. 2013. Why is $\mathrm{CaCO}_{3}$ not used as an additive in the pelletised chromite pre-reduction process? Minerals Engineering, vol. 45. pp. 115-120.

NiAyeSH, M.J. and FLETCHER, G.W. 1986. An assessment of smelting reduction processes in the production of $\mathrm{Fe}-\mathrm{Cr}-\mathrm{C}$ alloys. Proceedings of the 4th International Ferroalloys Congress, Rio de Janeiro, Brazil, 31 August - 3 September. Finardi, J., Nascimento, J.O., and Homem de Melo, F.D. (eds.). Associacao Brasileira dos Produtores de Ferro-Ligas-Abrafe, Sao Paulo, Brazil. pp. 115-123.

Nunnington, R.C. and BARczA, N.A. 1989. Pre-reduction of fluxed chromite-ore pellets under oxidizing conditions. Proceedings of the 5th International Ferroalloys Congress, New Orleans, USA, 23-26 March. Oxaal, J.G. and Downing, J.H. (eds.). Ferroalloys Association, Arlington, VA. pp .55-68.

PAKTUNC, D. 2001. MODAN - a computer program for estimating mineral quantities based on bulk composition: Windows version. Computers and Geosciences, vol. 27. pp. 883-886.

PAKTUnc, D. 2004. A computer program for analysing complex bulk XAFS spectra and for performing significance tests. Journal of Synchrotron Radiation, vol. 11. pp. 295-298.

Ravel, B. and Newville, M. 2005. Athena, Artemis, Hephaestus: data analysis for X-ray absorption spectroscopy using IFEFFIT. Journal of Synchrotron Radiation, vol. 12. pp. 537-541.

Riekкola-Vanhanen, M. 1999. Finnish expert report on best available techniques in ferrochromium production. The Finnish Environment 314, Environmental Protection, Helsinki, Finland.

SoKhanvaran, S. and Paktunc, D. 2017a. Carbothermic reduction of chromite ore using an industrial waste as the additive. Patent application. PCT/CA2017/051252 and US 15/788,953, 20 October 2017

SoKhanvaran, S. and PaKtunc, D. 2017b. The effect of fluxing agent on direct reduction of chromite ore. Proceedings of the Conference of Metallurgists, COM'2017. Canadian Institute of Mining, Metallurgy and Petroleum, Montreal. 13 pp.

Sokhanvaran, S., Paktunc, D., and Barnes, A. 2018. NaOH-assisted direct reduction of Ring of Fire chromite ores, and the associated implications for processing. Journal of the Southern African Institute of Mining and Metallurgy, vol. 118. pp. 581-588.

Takano, C., Zambrano, A.P., Nogueira, A.E.A., Mourao, M.B., and Iguchi, Y. 2007. Chromite reduction reaction mechanisms in carbon-chromite composite agglomerates at 1773 K. ISIJ International, vol. 47. pp. $1585-1589$.

VAn Deventer, J.S.J. 1988. The effect of additives on the reduction of chromite by graphite. Thermochimica Acta, vol. 127. pp. 25-35.

WANG, Y., WANG, L., and $\mathrm{CHOU}$, K.C. 2015. Effects of $\mathrm{CaO}, \mathrm{MgO}, \mathrm{Al}_{2} \mathrm{O}_{3}$ and $\mathrm{SiO}_{2}$ on the carbothermic reduction of synthetic $\mathrm{FeCr}_{2} \mathrm{O}_{4}$. Journal of Mining and Metallurgy, Section B: Metallurgy, vol. 51. 8 pp.

WEBER, R, P. and ERIc, R.H. 1992. Solid state fluxed reduction of LG-6 chromite from the Bushveld Complex. Proceedings of the 6th International Ferroalloys Congress, Cape Town, South Africa. Southern African Institute of Mining and Metallurgy, Johannesburg. pp. 71-77.

WinTER, F. 2015. Production of chromium iron alloys directly from chromite ore. Patent W02015/060951.

Yu, D. and PaKtunc, D. 2017. Carbothermic direct reduction of chromite using a catalyst for the production of ferrochrome alloy. Patent application, PCT/CA2017/050923 - 2017-08-02; US application 62/500,147.

Yu, D. and PAKTUNC, D. 2018a. Direct production of ferrochrome by segregation reduction of chromite in the presence of calcium chloride. Metals, vol. 8 , no. 1. p. 69. https://doi.org/10.3390/met8010069

Yu, D. And Paktunc, D. 2018b. Calcium chloride-assisted segregation reduction of chromite: influence of reductant type and the mechanism. Minerals, vol. 8, no. 2. p. 45. https://doi.org/10.3390/min 8020045

Yu, D. and PAKTUNC, D. 2018c. Kinetics and mechanisms of the carbothermic reduction of chromite in the presence of nickel. Journal of Thermal Analysis and Calorimetry, vol. 132, no. 1. pp. 143-154. https://doi.org/10.1007/s10973-017-6936-6 